\title{
Make Me Speak: A Mobile Apps for Children with Cerebral Palsy
}

\author{
Norshuhani Zamin ${ }^{1, *}$, Nursyafira Jamil ${ }^{1}$, Norita Md. Norwawi ${ }^{1}$ \\ ${ }^{1}$ Islamic Science Institute, Universiti Sains Islam Malaysia, 71800 Bandar Baru Nilai, \\ Negeri Sembilan, Malaysia.
}

\begin{abstract}
Cerebral Palsy (CP) is a common neurodevelopmental condition encountered by pediatricians. The condition may present itself in many different kinds of classification. In many cases, the cause of CP may not be apparent. Cerebral Palsy is always showing many deficits such as mental retardation, speech and language and oral motor problems. This project inspired from Elisya, a nine-year-old kid that has $\mathrm{CP}$ since born and she have the communication problems since she cannot speak to express her opinions and desires. The main focus on this project is to help to improve the communication issues among CP children. In order to assist the people with CP, the assistive tool is required to help them to communicate or interact with people around them. Assistive technology includes equipment, devices and software solutions that increase functional capabilities of people with disabilities and improve the quality of their lives. There are several Augmentative and Alternative Communication (AAC) devices for people with Cerebral Palsy that are not able to speak. One of the ways to make this happen is to implement the AAC technology with mobile technology by developing a mobile application named as Make Me Speak and React Native technology in order to build the cross platform for this application since the application should be run on IOS and Android platform so it's easier for other people to bring it anywhere and use it at any time. It also involves CP centres and school to do experimental studies for this project. There are several studies shows that AAC technology can help in enhancing the speech and language development and in this project, the suggested mobile application should be friendly to our language and culture of our nation, Malaysia and the project is in line with the social innovation in the Eleventh Malaysia Plan (RMK-11).
\end{abstract}

Keywords: Augmentative and Alternative Communication; Auditory Problem; Mobile Application; React Native

\section{INTRODUCTION}

According to the Channel News Asia, Sayfullah, a boy who has been diagnosed with Cerebral Palsy (CP) when he was one month old. He is able to recognize colors, shapes and numbers although he has communication problem which is he cannot talk and communicate with other people. The mother said that she or other people could see from his body language that he would like to tell lots of things such as his feeling, wishes and many more. They initiate a way to let him communicate with other people by implementing several Augmentative and Alternative Communication (AAC) technology [1] or known as assistive tool in mobile platform so he can just tap his finger on the screen and talk with other people.

The research was inspired from Elisya, a nine-year- old kid who has CP since she was born. She cannot communicate with other as she was born with auditory problem. In RMK-11, the social innovation is putting the government to focus more on streaming social services delivery by incorporating feedback from the community in line with the "whole-society approach instead of put higher investment in social services but delivery is ineffective. This initiative also encourage the Malaysian community to develop their idea into innovation instead of only remain dependent on the government.

\section{RELATED WORK}

According to the [2] The relation between Allah SWT and his slave is a relation based on the rights of Allah and the rights of His slaves. There are various types of justice which will be explained include social justice.

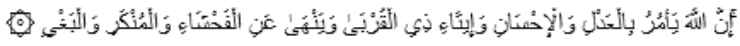

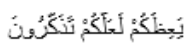

\footnotetext{
*Corresponding Author: Norshuhani Zamin, Islamic Science Institute, Universiti Sains Islam Malaysia, 71800 Bandar Baru Nilai, Negeri Sembilan, Malaysia, email: norshuhanizamin@gmail.com
} 
"Indeed, Allah orders justice and good conduct and giving to relatives and forbids immorality and bad conduct and oppression. He admonishes you that perhaps you will be reminded."

(Surah An-Nahl [19:90])

Social justice means to provide justice to every member of the society including people with disabilities irrespective of any discrimination, caste, creed and language. If there would be any preference, it would be absolutely based on knowledge, character and piety. Otherwise, one should have equal opportunity to take part in the development of the society so that every person gets chance to develop himself including those who delay behind and are covered up.

$\mathrm{CP}$ is a term that refers to a group of disorders affecting a person's ability to move due to the brain damages that happens before and during the baby's birth or during the first three to five years of the child's life. It also affects muscle tone, movement, and motor skills that can cause vision, hearing, speech problems and learning disabilities. In this kind of case, there are functional roadblocks that prevent effective communication between individual with $\mathrm{CP}$ and other people. When the child is nonverbal, it presents quite a challenge for people that are around them because the child cannot share their feelings, dreams or experiences through words [3]

For the $\mathrm{CP}$ children who are non-verbal, a speech pathologist identified the way for the child to describe themselves and their desire that substitutes speaking and promotes communication between people. To make sure that the goals are accomplished, the therapist will rely on physical cues, movements, conventional tools, and current technology to help a child to compensate for their limitations [4]. Some of these tools include:

- Gestures

- Symbols

- Signing

- Touching

- Picture boards

- Computer-based aids

- Voice synthesizers

The introduction of mobile technologies such as iPad and Android Tablet has offered many potential benefits to person with complex communication needs who require $\mathrm{AAC}$ to communicate [5] with other people such as:

- Increased awareness and social acceptance of $\mathrm{AAC}$ in the mainstream.
- Greater consumer empowerment in accessing AAC solutions.

- Increased adoption of AAC technologies.

- Greater diffusion of AAC research and technologies.

Oommen \& McCarthy [6] made a qualitative research study through an online focus group recruited across the world. The research included eight AHSAcertified speech-language pathologist implement AAC and natural speech services simultaneously for nonverbal children. This approach described as a step in grabbing a broader way of communication intervention for non-verbal children. This research going through six online focus group discussions and this session involved open-ended discussion topics facilitated by a moderator and designed to elicit responses regarding clinical implications, benefits, and challenges of adopting a dual-paradigm approach to intervention while working with children that unable to speak.

Overall, this study presents suggestive evidence to show the effectiveness of AAC intervention in conjunction with natural speech therapy for nonverbal children as a platform for intervention honouring multiple modalities in communication. There are three types of AAC users [7]:

\section{People Who Need an Alternative Language}

The user has good speech understanding and receptive internal language, but they miss the sensorimotor ability to produce a correct articulation of sounds that would be enable the speech process possible and understandable.

\section{People Who Need an Augmented Language}

The user does not quite understand speech nor they can intelligibly and coherently express themselves through speech. For this kind of user, the surrounding environment must be reorganized using labelling and symbols that they usual see and be able to understand and they will be able to integrate those symbols in an efficient communication approach.

\section{People Who Need AAC for a Certain Period of Time in Their Lives}

The user is either children who experienced a delayed emergence and development of language or adults who have lost ability to speak due to the disease such as stroke and have permanent disability.

An interview was conducted with Puan Nadwah Onwi, a speech therapist at a public rehabilitation centre. The center already decided to implement three types of technology in their treatment for language development for $\mathrm{CP}$ children as follows: 


\section{Head Pointer Assistive Tools}

Head pointer provide an alternative method of using equipment for people with limited had use and does not have ability to talk with other people. In Figure 1 , it shows that they will use the head pointer to tap on the screen.[8]

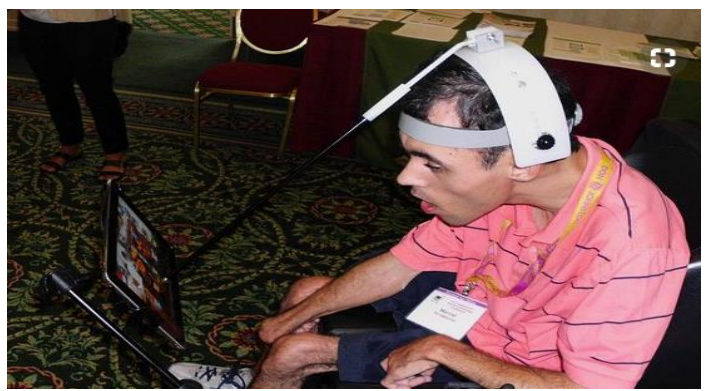

Fig 1 Head Pointer Assistive Tool

\section{Switch Access Scanning Assistive Tools}

Switch access scanning is an indirect selection technique, used by an assistive technology user, including those who use augmentative and alternative communication to choose option from the selection set. Scanning using technology has a good advantage that the user enables to be independent in controlling the assistive technology for those with only one voluntary movement as shown in Figure 2. [9]

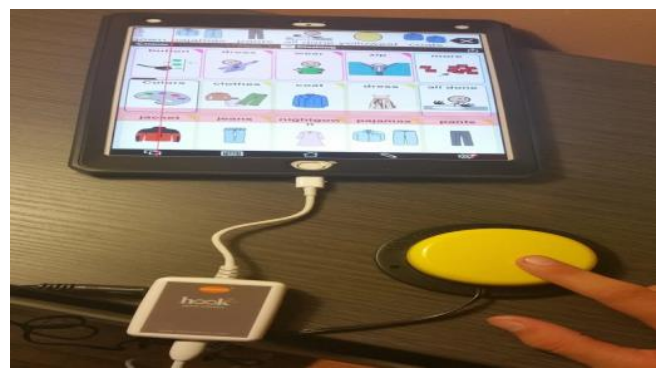

Fig 2 Switch Access Scanning Assistive Technology

\section{Eye Gaze Assistive Technology}

It is a method where called as eye-operated communication and control system that encourage people with disabilities to communicate and interact with other people. By looking at control keys or cells displayed on a screen, the user can generate speech either by typing a message or selecting pre-programmed phrases as shown in Figure 3[10]

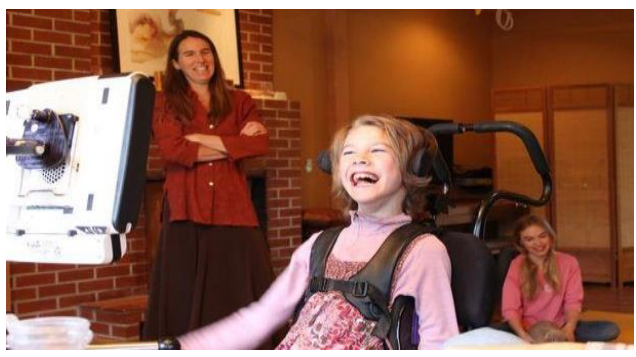

Fig 3 Eye Gaze Assistive Technology

The existing work for assisting the $\mathrm{CP}$ children gives inspiration for another similar application that suitable in our Malaysian community, since our national language is Malay language. It is easier for the parents and children to use the assistive mobile application without needing to learn English so Malaysians can use the mobile application including the citizens from the rural areas. The application will be able to assist the children in term communicate in a fun way, by tapping on their favorite pictures that their parents upload on the application and they also can hear the voice that familiar with them since the proposed mobile application will allow the user to upload their voice into the application. Table 1 shows some existing mobile apps that are found for $\mathrm{CP}$ children with auditory problem.

Table 1 Existing Applications

\begin{tabular}{|c|l|l|l|}
\hline Application & \multicolumn{1}{|c|}{ Platform } & \multicolumn{1}{c|}{ Strength } & \multicolumn{1}{c|}{ Limitation } \\
\hline AVAZ & IOS and Android & $\begin{array}{l}\text { Have consistent and } \\
\text { research based technology. } \\
\text { It can convert into a book, } \\
\text { so the application can be use } \\
\text { it offline and can } \\
\text { personalize the picture and } \\
\text { menu. }\end{array}$ & $\begin{array}{l}\text { The user interface of the } \\
\text { application is inconvenience } \\
\text { with CP children, not } \\
\text { available in Malaysia and } \\
\text { Malay Language. }\end{array}$ \\
\hline
\end{tabular}


Norshuhani, Nursyafira and Norita/ Journal of Engineering and Science Research,3(2) 2019, Pages: 21-26

\begin{tabular}{|l|l|l|l|}
$\begin{array}{l}\text { ACC } \\
\text { Speech } \\
\text { Buddy }\end{array}$ & Android & $\begin{array}{l}\text { The interface is nicely } \\
\text { organized and intuitive The } \\
\text { application also give the } \\
\text { user the ability to create, } \\
\text { customized, personalized } \\
\text { speech sets with others. }\end{array}$ & $\begin{array}{l}\text { The user need to buy the } \\
\text { application and the application } \\
\text { is not available in Malay } \\
\text { language }\end{array}$ \\
\hline $\begin{array}{l}\text { Tap To } \\
\text { Talk }\end{array}$ & IOS and Android & $\begin{array}{l}\text { Simple pictures organized in } \\
\text { a drill-down format help } \\
\text { kids communicate specific } \\
\text { messages. }\end{array}$ & $\begin{array}{l}\text { The user interface of the } \\
\text { application is inconvenience } \\
\text { with CP children, not } \\
\text { available in Malaysia and } \\
\text { Malay Language. }\end{array}$ \\
\hline ICom & IOS & $\begin{array}{l}\text { Available in free version. } \\
\text { IOS and Android }\end{array}$ & $\begin{array}{l}\text { The user interface of the } \\
\text { application is inconvenience } \\
\text { with CP children, not } \\
\text { available in Malaysia and } \\
\text { Than nine thousand easy to } \\
\text { understand images from } \\
\text { online directory. } \\
\text { available in IOS. }\end{array}$ \\
\hline alk & $\begin{array}{l}\text { The user interface of the } \\
\text { application is inconvenience } \\
\text { with CP children, not } \\
\text { available in Malaysia and } \\
\text { Malay Language. }\end{array}$ \\
\hline
\end{tabular}

\section{PROPOSED SYSTEM}

The interface above should greet welcome to the user that want to use the mobile application. In this page, the user needs to click start to use the mobile application and will need to proceed with language selection. This function has made our apps unique and different with the existing apps for CP. In Figure 5, it shows the idea for user interface for the proposed system.

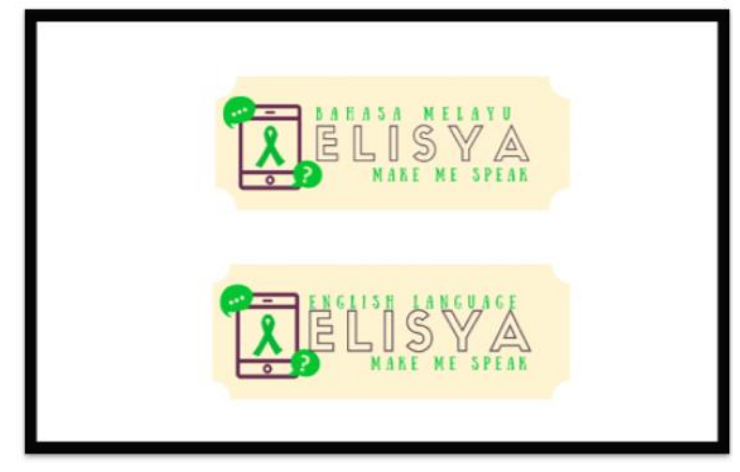

Fig 4 Language Selection Page

Next, 6 photos that shown on Table 2 are displayed on the screen and each picture will be playing an audio to help the CP child to communicate with other people. The $\mathrm{CP}$ child only require to tap on the pictures and the pre-recorded voice served as an audio to speak on behalf of the $\mathrm{CP}$ child.

Table 2 Malay Language Audio

\begin{tabular}{|l|l|l|}
\hline Type & Picture & Audio \\
\hline Food & & $\begin{array}{l}\text { "Saya mahu } \\
\text { makan." }\end{array}$ \\
\hline Drinks & & $\begin{array}{l}\text { "Saya mahu } \\
\text { minum" }\end{array}$ \\
\hline Sleep & & $\begin{array}{l}\text { "Saya } \\
\text { mengantuk. Saya } \\
\text { mahu tidur" }\end{array}$ \\
\hline Talk & & $\begin{array}{l}\text { "Saya mahu } \\
\text { bercakap dengan } \\
\text { awak" }\end{array}$ \\
\hline Poilet & & $\begin{array}{l}\text { "Saya mahu } \\
\text { pergi ke tandas" }\end{array}$ \\
\hline
\end{tabular}


The mobile application is developed for $\mathrm{CP}$ children who manage as screen device such as iPad but is are unable to speak. The apps can be applied on deaf children too. Survey on the public was conducted to test the rate of awareness on $\mathrm{CP}$ issues and children with $\mathrm{CP}$. An interview and observation were conducted on 9 year old CGP girl named Elisya. The results are discussed in the next section.

\section{RESULT AND DISCUSSION}

A survey was conducted on the public to get the views and opinions about $\mathrm{CP}$. The objective of the survey is to find out the awareness of the public on $\mathrm{CP}$ children and issues related to them. Few questions are asked and the results are shown below.

\section{HAVE YOU HEARD OF CEREBRAL PALSY?}

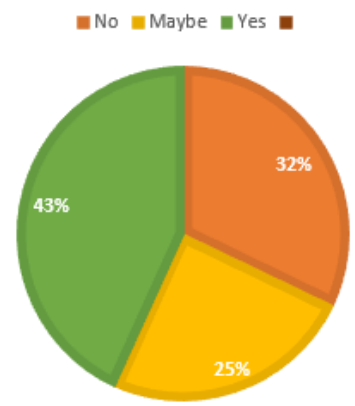

Fig 5 Survey Question 1

\section{HOW WOULD YOU RATE THE AWARENESS OF CEREBRAL PALSY IN MALAYSIA}

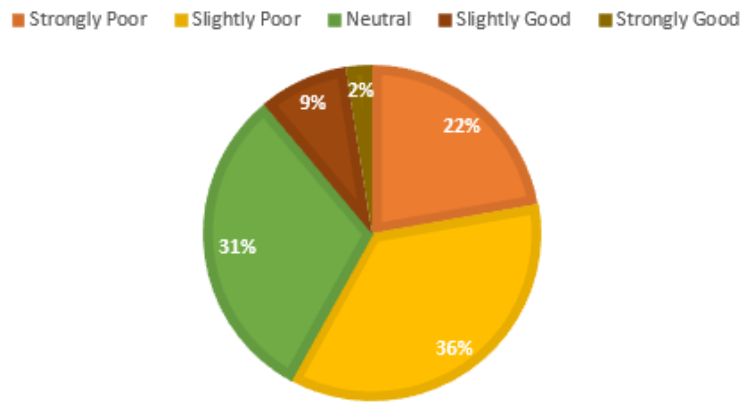

Fig 6 Survey Question 2

The results that shown in Figure 6 and Figure 7 indicate that many people are unsure about $\mathrm{CP}$. This is due to the lack of media coverage on CP in Malaysia. It is found that the awareness on Autism is pretty much higher that CP. There are many NGOs for autism than $\mathrm{CP}$ community. This also contributes to the low rate.

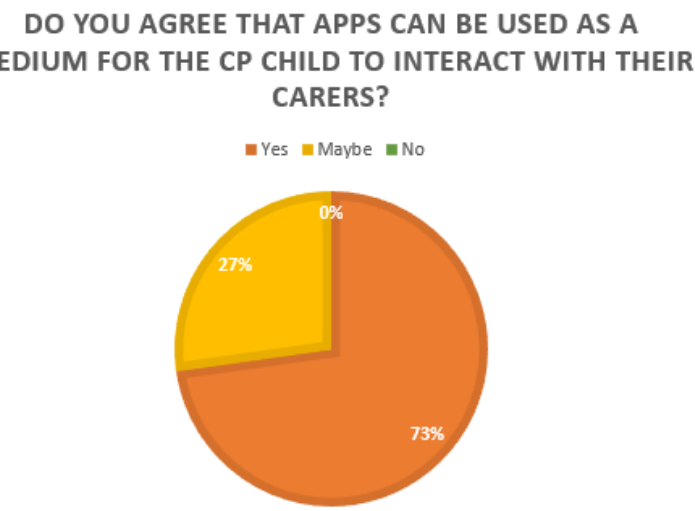

Fig 7 Survey Question 3

In this survey, we educate the public with some information on CP. Then, we asked them a question if they think they would support the use of mobile apps in assisting CP children with auditory problem. The result is shown in Figure 8. There are many people agree with the use of mobile apps since almost all people have mobile device such as tablet and smart phone in their home and it is easier to use the mobile application concept compare to the buying a new specific device on the purpose only.

An experiment with our developed mobile apps on a CP child named Elisya aged nine-year-old was conducted. An interview with the child's carer was also done to gain the info on the acceptance of the invention. Through the testing, we be able to see that Elisya be able to use the mobile application properly and she is happy while using the application. Before start the usability test, we also conduct a simple evaluation on Elisya's language development [11]. In this test, we asked Elisya to choose the correct shape and colour of the toy and she be able to choose and grab the correct toy by using her hand. A usability test was conducted, and the results were observed. We found that she was able to tap on the picture properly as compared to an existing mobile apps for CP children available on the market known as LetMeTalk [12], Make Me Speak apps has a wider screen display giving enough space for the $\mathrm{CP}$ child to tap on the picture.

The test setups are as follows:

1. The testing on Elisya's hand movements.

- We conduct this observation by how she hold the toys to prove the hand movement problem. Through this observation, her hand is quite shaky and it is difficult for her to control the hand movement due to the CP.

2. The testing on LetMeTalk apps that is available on the market was done with Elisya.

- Through this observation, we can see that she has difficulty to press the button on the application since it uses smaller buttons. 
3. The testing on Make Me Speak picture buttons.

- Through this observation, we can see that it is easier for Elisya to operate the buttons due to the bigger screen and physical divider we invented as an accessory on the iPad (Figure 9). The divider will prevent her finger to point to other picture button unnecessarily.

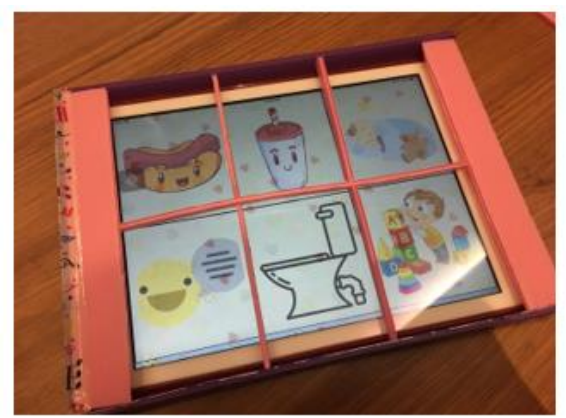

Fig 9 Plastic Physical Divider

\section{CONCLUSION}

People with auditory difficulties need an assistive platform to communicate with the people around them. The tool can be used for them to express their feelings and describe their desire. People with Cerebral Palsy who are unable to communicate properly need a platform for them to interact with other people so AAC technology helps them to communicate more easily and effectively. Our mobile apps is able to help to overcome the difficulty of speaking and increase the independency level. Our studies found that the children who are unable to talk can enhance their speech and language development with the apps technology.

\section{REFERENCES}

[1] Simion, E. (2014). Augmentative and Alternative Communication - Support for People with Severe
Speech Disorders. Procedia - Social and Behavioral Sciences, 128, 77-81.

[2] Nawaz, M. (2015). Right of Justice Among Basic Human Rights In The Light Of Islam. Retrieved July 23, 2018, from https://vfast.org/journals/index.php/VTIR/article/vi ew/279/33

[3] Miller, F., \& Bachrach, S. J. (2006). Cerebral Palsy: A Complete Guide for Caregiving. Baltimore: Johns Hopkins University Press.

[4] Lennon, S., Ramdharry, G., \& Verheyden, G. (Eds.). (2018). Physical Management for Neurological Conditions E-Book. Elsevier Health Sciences.

[5] McNaughton, D., \& Light, J. (2013). The iPad and mobile technology revolution: Benefits and challenges for individuals who require augmentative and alternative communication.

[6] Oommen, E. R., \& McCarthy, J. W. (2015). Simultaneous natural speech and AAC.

[7] Webb, W., \& Adler, R. K. (2016). Neurology for the Speech-Language Pathologist-E-Book. Elsevier Health Sciences.

[8] Gips, J., Zhang, M., \& Anderson, D. (2015). Communication System for People with Disabilities.

[9] Erdem, R. (2017). Students with special educational needs and assistive technologies: A literature review. Turkish Online Journal of Educational Technology-TOJET, 16(1), 128-146.

[10] Borgestig, M., Sandqvist, J., Parsons, R., Falkmer, T., \& Hemmingsson, H. (2016). Eye gaze performance for children with severe physical impairments using gaze-based assistive technology - A longitudinal study. Assistive technology, 28(2), 93-102.

[11] Lenneberg, E. H., \& Lenneberg, E. (Eds.). (2014). Foundations of language development: a multidisciplinary approach. Academic Press.

[12] LetMeTalk App English. (n.d.). Retrieved July 25, 2018, from http://www.letmetalk.info/ 